\title{
Government Ambiguity: Between Accommodation and Discrimination of Identity in Multicultural Society
}

\author{
Khoirun Nisa \\ \{khoirun.nisa@uinjkt.ac.id\} \\ Universitas Islam Negeri Syarif Hidayatullah Jakarta, Indonesia
}

\begin{abstract}
Indonesia has a concept 'unity of diversity' to synthesize a plurality of identities -religions, ethnics, cultures, etc-. In realizing this concept, the government should be an agent to provide harmony within a multicultural society. Unfortunately, this study oppositely illustrates the policy of a local government which tends to result in less tolerant attitudes toward minority religion. This study examined Tangerang City as a case study during Wahidin Halim as a mayor in tenure 2009-2013. The study shows how a local government applied different policies toward majority and minority groups. The government used Islamic symbols in public spaces to convey the local government's vision, whereas, Santa Bernadet parish (Catholics Church) struggled to fight worship rights. The propensity of intolerance government attitude could be seen when religion intertwined in political interest. The Multiculturalism perspective is used to analyze this case to see how the state appropriately treats plural societies. This study gathered data through interviews of local leaders and representatives from the Catholics group.
\end{abstract}

Keywords: Local Government, Islamic symbol, Catholics, Identity Politics, Multiculturalism

\section{Introduction}

Indonesian founding fathers agreed that Indonesia is a multicultural country and Pancasila as final ideology in continuing the ideals of Indonesia's independence. Indonesia has diversities of identities, such as ethnics, traditions, languages, religions, etc. Indonesia has six official religious which recognized by state. Furthermore, The Constitutional Court of Indonesia issued a decision concerning Prevention of Abuse and Blasphemy of Religion. This regulation reveals that the state does not limit recognition or protection to only six religions, but also the state recognizes all religions practiced by Indonesian population. In other words, Indonesia government provides protection for freedom of religious expression as affirmed in article 29 of the 1945 Constitution.

Indonesia emphasizes Bhinneka Tunggal Ika (unity in diversity) as nation's motto, whereas the problem of religious freedom in Indonesia never ends. For instance, the establishment of churches often faces obstacles. Numerous studies show how churches establishment especially Catholics often get resistance from majority society who are predominantly Muslim. They are fear of Christianization issue. This issue was proven in research conducted by the Paramadina Foundation Research Team, Masters in Peace and Conflict Resolution at Gadjah Mada University (MPRK-UGM) and the Indonesian Conference on Religion and Peace (ICRP) in several regions in Indonesia, such as Medan, Banjarmasin, Jakarta, Yogyakarta, Bali, Makassar and Papua. The results of this study indicate 
that the polemic over the construction of churches was caused by the weakness of government officials in upholding justice [1].

The fear of some majority group on the issue of Christianization is basically contrary to the teachings of Islam itself. Islam as majority religion of the Indonesian people teaches how to recognize differences and provide opportunities for other people to worship according to their beliefs. Muhammad as a role model for Muslims was the originator of multiculturalism in human history. Multiculturalism itself has a meaning as a normative response to the fact of cultural diversity[2]. The real fact carried out by the Prophet was the recognition of diversity between Muslims and non-Muslims in Medina, known as the Medina[3].

In resolving the church establishment case, the government issued Joint Ministerial Regulations (PBM) Number 9 and 8 of 2006. Unfortunately, this regulation is considered not able to solve the problem. One of requirement in that regulation asked an approval from local residents to build houses of worship. By this regulation, Catholics group face a difficulty since they get stereotypes from the community related to the issue of Christianization (Republika 2019). Even the Indonesian Solidarity Party (PSI) intends to regulate the PBM because it is considered problematic [4].

Ironically, amid the difficulties of minority identity- Catholics- getting permission to establish a church, some local governments after reformation era use identity politics by using majority symbols as their persuasion of the community. Moreover, they conduct this political practice for getting electoral interests. Local governments provide a large portion of accommodation for the majority group. Anthony Downs argues that political parties do not actually try to win elections in order to implement policies, but instead they formulate policies in order to win elections [5]. That is, Islamic sharia regional regulations are used as political tactics to win elections. There are several examples of the application of Islamic sharia in Indonesia, such as rules on Muslim dress for school children and female public servants, regulations on literacy for prospective brides, the existence of Islamic symbols in public spaces, etc [6][7].

Likewise, the Tangerang City government used the concept of collective goals by majority language. Furthermore, some Islamic symbols can be found in Tangerang City public spaces since 2009. On the other hand, the construction of a church in the city of Tangerang became very problematic and colored by conflicts. A minority identity did not get full worship rights as guaranteed in Article 29 of the 1945 Constitution.

This paper illustrates how ambiguity attitude of the government who provides policies to the majority but neglects worship right of minority. Furthermore, this paper discusses multiculturalism perspectives as state role in multicultural societies. This paper is based on research of qualitative methods. Data comes from interviews with four resource persons. They are Wahidin Halim as the mayor of Tangerang City in period 2013-2019 and three representatives from Catholics group ( 1 religious leader and 2 people from male and female religious organizations).

\section{Identity Politics in Tangerang City}

Tangerang City is a capital buffer of Jakarta and an industrial city. This city becomes a target for villagers to work in metropolis. No wonder, this city is fulfilled with identities groups from many regions in Indonesia. Tangerang City has diversity of ethnics, religions, tradition, and languages. Cina Benteng is the most famous and unique ethnics in Tangerang 
City. Cina Benteng ethnic is an old community which proofed by the existence of ancient temple, namely Boen Tek Bio. This temple established since 1684 and located in Pasar Lama as China town of Tangerang City. Cina Benteng ethnics acculturated with local culture of Tangerang and captured in some special arts, such as Cokek dance, Gambang Kromong music, Chiou Thao marriage tradition and so on [8]. Tangerang City government carries out Cisadane festival in every mid year as a recognition of identities diversity. For example, PeCun as a holy day of the Confucian community is celebrated by rowing boat race and become characteristic of Festival Cisadane event. Various activities also color the festival, such as releasing ducks into the river, standing egg attractions, making bakcang, washing ancient boats, lion dance, local art performances, folk art parades, traditional food competitions, business exhibitions and other activities [9].

In other side, since 2009, Tangerang city government used Islam -majority identity- as identity politics. Wahidin Halim, as the mayor at the time, used many symbols in public spaces to convey the local government's vision. This political practice was triggered by the issuance of regional autonomy policy as a form of expression of freedom in the reform era. Moreover, the existence of Muslims as a majority group increasingly legalized the phenomenon of the rise of Islamic politics that were previously marginalized by the New Order system [7]. Identity politics used as political tool of a group -ethnicity, culture, religion, etc- for certain goals as a form of resistance or as a tool to show one's identity [10].

This chapter discusses how Tangerang City government gave priority for majority identity. Akhlaqul karimah (Respectful Behaviour) is a main reference to the presence of various Islamic symbols in the public sphere. The concept of akhlaqul karimah was initially motivated by the anxiety of the Tangerang City government towards the decrease of community spirituality and morality. This symptom is characterized by increased criminality and some immoral practices -prostitution or intoxication- which is responded by some people as no longer taboo. Likewise, the stereotypes of KKN (Corruption, Collusion and Nepotism) are inherent in the image of government employees as community protectors. Departing from this reality, the Tangerang City government was inspired to make a big change. The choice fell towards the concept of akhlaqul karimah which was considered as the right response in answering the above problems.

For the government, akhlaqul karimah concept not only teaches the values of goodness, but the religiosity image also presents $t$ in the concept. In this case, Islam as the belief of majority becomes a strong motive in implementing the akhlaqul karimah policy further. Akhlaqul karimah is an implementation of the great concept taught by the Messenger of Allah in building civil society. Muhammad was the most successful figure to unite the plural Arab community at that time into a joint agreement, namely the Medina Charter. Therefore the government system and the foundation of community life must be united in moral values that originate from Islam. This is an effort to uphold justice and avoid greater tyranny [11].

The socialization akhlaqul karimah concept to the community was carried out through several media. Some Islamic symbols can be found in public spaces, such as the word Allah Allah (God) and al- AsmaulHusna (The names of God) are used in many public signs in main roads. Akhlaqul karimah words popularized in the form of slogans, billboards, banners in city main roads. A mosque is used as the city icon for the City Government next to the local government offices. Akhlaqul Karimah is as well manifested in City Regulation on Muslim Dress Code for Students and government employees, No-Alcohol and No Prostitute Regulations, Education Provision Regulation, Pilgrims Health and Transportation Regulations. The government also conducts monthly Islamic study sessions at the residence of Mayor Wahidin Halim, and various other policies [12]. 
The concept of akhlaqul karimah was socialized in the form of Five Commitments to Build Akhlaqul Karimah of Tangerang City Government Employees. It was government effort to instill a variety of good values to its employees, such as honesty, discipline, togetherness, creativity. Government also emphasizes that work is part of worship, so that the government employees are able to serve the community as well as possible. In addition, government implemented regulation concerning the Prohibition of Smoking for Employees, Students, Teachers and Education Personnel. This policy is an effort to restore the good image of the government as a role model for all elements of society. Not only in attitude, the Tangerang City government succeeded in proving changes in the quality of work performance. This is demonstrated through various achievements in the fields of education, finance, environment, public services, informatics, infrastructure, health, urban planning and etc [12].

Even though, the leadership of Tangerang City government has changed, from Wahidin Halim (2003-2013) to Arief Wismansyah (2013-now). Akhlaqul Karimah concept is still becoming local government's vision. Likewise, Islamic symbolizations are still coloring public sphere of Tangerang city.

\section{A Struggle for Worship Right}

Santa Bernadet is a parish which struggling to fight for the rights of its people to worship safely and comfortably. This is actually a simple request that comes from a minority to be treated same as other Indonesian citizens, but in reality this desire is very difficult to realize. Year after year, the life of the parish church was passed with full of pressure and intimidation from certain groups, so that the parish is now 27 years old. It was a long and very tiring and exhausting journey.

St. Bernadet is one of the parishes in Tangerang City. Based on its history, the proposed establishment of the Parish of St. Bernadet came from a priest of Santa Maria Parish, namely Father S. Bintarto, SJ in 1987. Parish of St. Bernadet was initiated to serve Catholic Christians in Karawaci, Serpong, Tanjung Kait and Ciledug. The start of the parish center was held at the priest's residence on Jl. Barata Raya No. 29 Ciledug. (santabernadet.id). Over time, the number of parish members has increased. The priest's house which was used as a place of worship no longer able to accommodate the needs of members of the Santa Bernadet. Finally, the people of St. Bernadet borrowed 3 places for worship. (1) Archive Building for the Ciledug Financial Housing Complex (owned by the Ministry of Finance), (2) LokaGentaBakti Building in the Ciledug Indah Complex (Oikumene worship facility), and (3) the High Building of the Ciledug National Police Dormitory Building (owned National Police). After the land purchase was carried out in December 1989, Jakarta Archbishop, Leo Soekoto SJ suggested the parish to immediately build a community center in the form of a temporary church [1].

In 1990, the Church Construction Committee submitted a Building Permit to the local Government. However, the government refused on the grounds that the building was not allowed to be used as a place of worship. As a way out, the Santa Bernadet parish submitted a request to build a school on behalf of Sang Timur Foundation. The local government granted the request with Tangerang District Head Decree No. 642.2/409-PERK/1990. The committee also takes care of permits to residents and declares responsibility in case of road damage due to construction trucks because it used the Finance Department Complex road for building material traffic. Finally, the church construction committee obtained permission from the local 
government and the community to establish schools. Unfortunately, in the process of building a church, some local residents rejected and closed the road because they claimed the school building resembled a church. School construction can also be done again after obtaining permission from the finance minister at that time.

On July 21, 1992, the Karang Tengah Village Head issued a recommendation letter regarding the usage of the Sang Timur School for worship and religious activities. On the basis of the letter, the committee used Sang Timur School as a center for the activities of St. Bernadet members. Unfortunately in 2004, the Department of Religion of Tangerang City issued a letter to the Principal of Sang Timur School and requested to stop using the school building as a place of worship. Not only that, the Karang Tengah Village Head also revoked the permit to use the Sang Timur School as a place of worship that had been given previously. Base on of this letter, a group of people protested against the construction of a multi- purpose building. This opposing group was in the name of the 'Front Pemuda Islam' (FPI) Karang Tengah. They put up banners and held demonstrations on August 15 and 28, 2004, opposing the existence of Sang Timur and the planned construction of the Santa Bernadet Multipurpose Building. On October 3, 2004, Mass service led by Father Derikson was forcibly terminated and anarchist by the Front. Church Administrator St. Bernadet was forced to make a statement to stop the worship activities at Sang Timur School forever. This signing was carried out under pressure from opponents. This letter later became the basis of the opposing group to wall the Sang Timur gate, which the opponents claimed was owned by residents and did not allow church people to walk through the road. The police could not be do much and not be able to be an active mediator. Even, the new Mayor of Tangerang City at that time, Wahidin Halim, did not get a serious response.

St. Bernadet must start from the beginning of the development process church. Since the events of the roadblock and opposition, people forced to worship in homes. For holiday activities, since the large number of people, renting a building is an option that must be taken. The location of the church plan was moved to new land was bought in 2001 in Kelurahan Sudimara Pinang.The committee then transferred the location of the church construction in 2009. At that time, Wahidin Halim was re-elected as Mayor. He won a landslide victory with 80 percent of votes. Some information states, when the parish asked for help, Wahidin Halim again ignored and said that his victory was not due to the support of Catholics. For him, Catholics choose or not, not much means it. Departing from this, how far a regional head feels the need for support from non-Muslims affects the "fate" of licensing houses of worship. Even the issue of Christianization remains labeled to the community of Santa Bernadet. Religious activities in the social form, such as providing free medical treatment and private lessons, are always misinterpreted by the majority community. They do private tutoring activities because many of the members of the Santa Bernadet are retired teachers, so they are able to do that activity as a form of social activities required by their religion. All religions are oriented to the spread of virtues. The informants revealed, they were surprised by the majority group who were very afraid of the construction of the church because it would reduce their faith.

The struggle was finally answered on September 11, 2013. Santa Bernadet Parish eventually having permission to build a church after 23 years of struggle. But 11 days after the permit was issued, on Sunday, September 22, 2013, hundreds of people wore white shirts and red headbands were demonstrating in front of the parish ground and forcibly padlocked the church fence. The demonstrates argued that the Parish of Santa Bernadete had a violation of the Joint Ministerial Decree (SKB) 2 on the Establishment of Houses of Worship, particularly Article 13, related to the establishment of houses of worship which must be based on real needs and based on the composition of the population for the service of the people concerned. 
The demonstrators also stated that the construction of the church violated Article 14 of the Minister's Decree 2 regarding the support of a minimum of 60 residents authorized by the headman of village. They also questioned the use of the hall in the Tarakanita complex as a temporary place of worship, and worried about the possibility of Christianization if the church was founded. (Tempo.co, 23/09/2013, Beritasatu.com, 23/09/2013). After going through various rejections, the Parish of Santa Barnadet eventually build in a housing complex, Jl. Boulevard Graha Raya, Sudimara Pinang, Tangerang City.

\section{The Propensity of Intolerance State and How State Appropriately Threats Multicutural Society}

The attitude of a local government tends to imply intolerance policy could be clarified by these two explanations which come from Andrew Bramsen and Zoe Vermeer in their article. They examined why Muslim majority state implies religion regulation higher rather than non Muslim state. Firstly, Muslim states are on average much less regiliously pluralistic than nonMuslim states. This context could result intolerance government attitude. By this explanation, Kota Tangerang could be included as multicultural society, which has diversity of identities and muslim as majority identity. Secondly, religion and politics are much more intertwined in the foundations of Islam than the other religious tradition. Religious regulation is seen as legitimate and a positive [13]. In the context of Tangerang City, the local government uses a concept of the good from majority identity language in conveying the vision of city development. This is strongly believed by the government to bring the people of Tangerang City towards a better direction. The identity politics used as a tool to convince society a better future and this strategy suceed by Wahidin Halim winning election for second period. He got $80 \%$ votes in election. Furthermore, Tangerang City achieved many appreciations in education, finance, environment, public services, informatics, infrastructure, health, urban planning and etc. It can be said that identity politics legitimate as a positive good which enormously impacted Tangerang City to significant development.

Bhinneka Tunggal Ika (unity in diversity) is Indonesia's motto which describes how plurality in Indonesia. This country has diverse ethnics, cultures, traditions, languages, etc. Bikhu Parekh, a political expert from England, defines multicultural and multiculturalism differently. In his book, Rethinking Multiculturalism, Parekh explains the term multiculturalism as a reality of cultural diversity. Whereas multiculturalism is a term that refers to a normative response to the fact of diversity [2]. It means, when discussing multiculturalism, it would refers to how aspects of the fact of diversity are responded normatively. When referring to a society, the role of the state to act normatively over the diversity of its people is a demand.

In terms of multiculturalism theory, Bikhu Parekh reveals that the dominance of government through dominant identity creates an unbalanced state. Majority has been an exclusive identity. For instance, they able to enjoy state protection, gaining power and access to valuable resources, respecting the public, and even determining the voice of all members of society. While other identities that only grow in the private sphere, are in the shadow of the group's dominating power and are generally seen as marginalized [2]. Feelings as a secondclass group are as felt by some Catholic Christian communities. This was revealed by them in the interview session, "With the symbols of Islam we feel irritated as a minority". In other 
words, the government does not act as a protector of the plurality instead they act unjustly and cause discrimination.

In multicultural societies, special conceptions of life (the goodness of life) are subjective which are determined by their respective identity groups. According to Charles Taylor, everyone has a measure of morality in accordance with his believes. This is part of human dignity, which gives individuals wide autonomy to determine their own views of a good life. Beneficial conception is largely determined by the identity inherent in each individual and each identity is a source of goodness [14]. However, it does not mean that multiculturalism does not simply accept and acknowledge all cultures, but it also responds critically to the culture adopted [2]. In other words, recognition of the existence of various cultures does not necessarily mean justifying all religions, but testing them formatively. Ethics will always be a parameter in discussions about good or bad. In the Indonesian context, the context of honor refers to the values of Pancasila. What must be done by the Tangerang City government in accommodating groups identities has broken up justice value in the 5th precepts of the Pancasila.

What is quite interesting about multiculturalists thinking is their perspective on the value of equality in plurality. For example, for Parekh, equality is not seen through uniformity and equal treatment, but must be seen based on differences owned by humans. By nature, humans are culturally different, so equal treatment only forms humans in one particular direction and differences blind. Parekh insisted that equality involved five things. First, freedom and opportunity to be different. Second, equal treatment to consider similarities and differences. Third, respect and rights. Fourth, opportunity, self-confidence and self-esteem. Fifth, power, welfare and basic ability to develop humans [2]. These five things imply that equality must be accompanied by sensitivity to differences. That is, the value of equality involves different treatments according to the needs of cultural groups. This is a form of accommodation to make cultural groups that are not in a favorable condition equal to the majority group.

Likewise, stated by Will Kymlicka, giving special rights for minority groups to achieve their equality is the right thing for a country to give recognition to identity groups [15]. If this multiculturalism perspective is placed in the context of the City of Tangerang, it can be said that the government made the akhlaqul karimah policy as a form of accommodation to the majority group. An identity accommodation is key word in the perspective of multiculturalism. However, at the same time, the government violated the value of multiculturalism itself, the recognition and accommodation of minority groups.

\section{The Conclusion}

The government tends to less tolerant attitudes toward minority religions when religion and politics are intertwined in state which identity politics used as a tool for winning election of leader local government. The government needs to put multiculturalism perspective as a basic consideration of policy making. The minority group should be accommodated as well as majority group. The value of equality involves different treatments according to the needs of cultural groups. 


\section{References}

[1] I. Ali-Fauzi and dkk, Kontroversi Gereja di Jakarta. Yogyakarta: Program Studi Agama dan Lintas Budaya, 2011.

[2] B. Parekh, Rethinking Multiculturalism: Cultural Diversity and Political Theory. Massachusetts: Harvard University Press, 2000.

[3] B. Yatim, Muhammad SAW di Madinah. Jakarta: Ichtiar Baru Van Hoeve, 2002.

[4] "PSI Usulkan Penghapusan SKB Menteri Soal Tempat Ibadah," Republika.co.id, 2019. [Online]. Available: https://www.republika.co.id. [Accessed: 12-Feb-2019].

[5] A. Downs, An Economic Theory of Democracy. Harper, 1957.

[6] W. Trianita, The Formalization of Shari'ah in Cianjur. Jakarta: PPS UIN Jakarta, 2008.

[7] S. Kamil and C. S. Bamualim, Syariat Islam dan HAM, Dampak erda Syariah terhadap Kebebasan Sipil, Hak-Hak Perempuan dan Non Muslim. Jakarta: CSRC UIN Jakarta, 2007.

[8] W. Halim, Ziarah Budaya Kota Tangerang: Menuju Masyarakat Peradaban Akhlakul Karimah. Tangerang: Pendulum, 2005.

[9] "Laporan Program Pengembangan dan Pemasaran Pariwisata (Festival Cisadane)," Tangerang, 2009.

[10] M. Castells, The Power of Identity. Oxford: Blackwell, 2004.

[11] W. Halim, Piagam Akhlaqul Karimah Meretas Jalan Masyarakat Madani. Tangerang: Pendulum, 2006.

[12] D. H. Infokom, “Kota Tangerang dan Berbagai Prestasi," Tangerang, 2010.

[13] A. Bramsen and Z. Vermeer, Religious Regulation in Muslim States. New York: Oxford University Press, 2019.

[14] C. Taylor, The Politics of Recognition." In Multiculturalism, by Amy Gutmann. New Jersey: Princeton University Press, 1994.

[15] W. Kymlicka, Multicultural Citizenship: A Liberal Theory of Minority Right. New York: Oxford University Press, 1995. 